\title{
Selection of RAPD primers for geographically most distinct Lithuanian populations of Impatiens parviflora
}

\author{
Rasa Janulionien $\dot{e}^{\star}$, \\ Judita Žukauskienè, \\ Milda Jodinskienė, \\ Daiva Ambrasienė, \\ Algimantas Paulauskas, \\ Eugenija Kupčinskienè \\ Department of Biology, \\ Vytautas Magnus University, \\ Vileikos 8, LT-44404 Kaunas, \\ Lithuania
}

\begin{abstract}
Surprisingly little information is available about adaptations of invasive species in the Baltic countries. Since 1934 Impatiens parviflora DC. was recorded in the suburbs of Vilnius, supposedly it escaped from the VU Botanical Garden. Presently I. parviflora belongs to naturalized species of active distribution. In Lithuania, I. parviflora occurs abundantly in man-disturbed localities - urban sites, roadsides or farmyards. Permanently overmoistured gleyic forest sites are also common habitats of I. parviflora. Our study aimed at selection of RAPD primers for evaluation of genetic variability among geographically contrasting four populations of I.parviflora. Populations growing near the western, southern, northern and eastern borders of Lithuania (Karklè, Ratnyčia, Žagarè, Švenčionys) were selected. Randomly Amplified Polymorphic DNA (RAPD) as the most ubiquitous for plant analysis molecular markers type was selected for evaluation of genetic diversity of I. parviflora populations. Among thirty RAPD primers tested, 222, 250, 269, 340, 474, 516, OPA-20, OPB-7, OPD-20, OPQ-11 generated the largest amount of DNA bands and were selected for the analyses. For each population, the percentage of polymorphic bands with ten primers was 21-27 (the lowest for Karkle and the highest for Žagare population), and the number of polymorphic bands ranged in the interval 40-50. Molecular variance among populations was much higher (82\%) than within populations. Varying geographically, populations of I. parviflora were sufficiently distinct according to RAPD based principal component analyses, also by UPGMA dendrograms. Pair-wise genetic distance among these populations ranged from 0.349 to 0.583 . The obtained data show that distribution of invasive species might bring changes in genetic diversity.
\end{abstract}

Key words: small balsam, Balsaminaceae, polymorphism, invasion, alien species

\section{INTRODUCTION}

Globalisation provides vastly expanded opportunities for plant species to be transported to new locations through a wide range of pathways [1]. Alien species might have serious implications for the environment and communities. Urgent problems of Europe include pathways of invasion and elucidation of species traits in determining invasiveness [2]. After introduction of I. parviflora to European botanical gardens at the beginning of the 19th century (e. g.

\footnotetext{
* Corresponding author. E-mail: ra.janulioniene@gmail.com
}

1837, in Dresden), its intervention to the natural communities was soon observed [3]. It is supposed that in Lithuania I. parviflora escaped from the VU Botanical Garden and in 1934 it was recorded in the suburbs of Vilnius for the first time [4]. Within the last decades in many European countries great attention has been paid to Impatiens glandulifera $[5,6]$. Investigations of behaviour of sister species, small balsam, are surprisingly scarce despite the fact that it belongs to naturalized species of active distribution [7], presently being very common for cities and intervening deciduous forest communities $[8,9]$. There is lack of information regarding local differentiation of both alien Impatiens 
species of the Baltic region [7, 10]. Till now Impatiens spp. data available for this area mainly deal with geographical location, morphology and lists of species comprising communities $[10,11]$. The present study aimed at evaluation of genetic diversity of I. parviflora populations growing in the most geographically contrasting areas of Lithuania. This is an initial step in evaluating populations of small balsam throughout the country.

\section{MATERIALS AND METHODS}

Plant material. I. parviflora was collected from the most contrasting according to the geography areas of Lithuania (Table 1): near the west border of Lithuania - Karklè, near the east border - Švenčionys (distance between Karklè and Švenčionys is $330 \mathrm{~km}$ ), near the north border - Žagare and near the south border - Ratnyčia (distance between Žagare and Ratnyčia - $268 \mathrm{~km}$ ). Sampling date was July 21-August 1, 2010. Aboveground parts of the plants were cut, sealed in separate bags, cooled and transported to the laboratory. Leaves from the top of the plants were cut and frozen under $-20^{\circ} \mathrm{C}$.

DNA extraction and RAPD-PCR. Total DNA was extracted from frozen leaves. Approximately 100-150 mg of plant material was grinded with liquid nitrogen and transformed to $200 \mu \mathrm{l}$ Tris-EDTA buffer with $400 \mu$ lysis solution (Genomic DNA Purification Kit, \#KO512, Fermentas, Lithuania). The concentration and purity of DNA samples were determined spectrophotometrically (Eppendorf BioPhotometer, Germany), other details of DNA extraction have been described earlier [12]. $0.5 \mu \mathrm{l}$ RNase A/T1 Mix (\#ENO551, Fermentas, Lithuania) was applied. For RAPD analysis 10 oligonucleotide primers of $10 \mathrm{bp}$ length were used (Biomers.net $\mathrm{GmbH}$, Germany). PCR mix in a volume of $25 \mu \mathrm{l}$ consisted of $4 \mu \mathrm{l} \mathrm{DNA}, 2.5 \mu \mathrm{l}$ Taq reaction buffer, $0.2 \mu \mathrm{dNTP}(25 \mathrm{nM}), 1.5 \mu \mathrm{MgCl}_{2}(25 \mathrm{nM}), 2 \mu \mathrm{l}$ primer $(10 \mathrm{pmol} / \mu \mathrm{l}), 0.25 \mathrm{Taq}$ DNA polymerase (MBI Fermentas, Lithuania) and $14.55 \mu$ ldeionised water.

RAPD analyses. DNA amplification was performed in Mastercycler gradient (Eppendorf, Germany) according to the following program: first denaturation for $2 \mathrm{~min}$ at $94^{\circ} \mathrm{C}$;
35,40 or 45 cycles of denaturation for $30 \mathrm{~s}$ at $94^{\circ} \mathrm{C}$, primers annealing for $35 \mathrm{~s}$ at $32^{\circ} \mathrm{C}$ or $34^{\circ} \mathrm{C}$ (depending on primer: the same as melting temperature or lower), extension for $1 \mathrm{~min}$ at $72{ }^{\circ} \mathrm{C}$ and final extension for $2 \mathrm{~min}$ at $72{ }^{\circ} \mathrm{C}$. The reaction products were fractionated by electrophoresis in $1.5 \%$ agarose gel with ethidium bromide and the photographs of gels in the UV light were taken using Herolab transilluminator (Germany). The length of bands were estimated according to the gene ruler (GeneRuler ${ }^{\mathrm{TM}}$ DNA Ladder Plus with the standard molecular marker of $100 \mathrm{bp}$, Fermentas, Lithuania).

Statistical analyses. Genetic distances between populations $\left(\mathrm{GD}_{\mathrm{xy}}\right)$ were calculated according to Nei and Li [13], and based on these data UPGMA grouping methods were applied. Molecular genetic diversity analysis was performed using GenAlEx v 6.41 program [14].

\section{RESULTS AND DISCUSSION}

Thirty RAPD primers were tested for amplification with I. parviflora DNA. Ten most informative primers were applied analyzing 4 populations (Table 2). Selected RAPD primers generated from 14 to 22 bands each, most of the bands (13-20 bands in primer) were polymorphic, and percentage of polymorphic bands was $89-100$, respectively. Merely a few bands in some primers (1-2 bands in primer) were monomorphic. DNA band size ranged from $210 \mathrm{bp}$ to $2900 \mathrm{bp}$. The shortest bands were generated by 222 primer, while the longest one by OPA-20. More detailed analyses of separate RAPD primers generated DNA (Table 3 ) showed that 474 primer was very efficient in generating bands for all populations. However, all populations with 516 primer, and populations of Ratnyčia, Karklè - 340 primer, Švenčionys, Žagare - OPQ-20 primer were monomorphic, and OPD-7 (Švenčionys $71.4 \%$ polymorphic bands) primer, and 474 primer (Švenčionys $63.2 \%$ and Ratnyčia $57.9 \%$ polymorphic bands) were most polymorphic.

Number of different bands with a frequency $\geq 5 \%$ ranged in the interval 91-106 highest for Švenčionys population (Fig. 1). Number of locally common bands found in $\leq 50 \%$ populations was $23-28$. Expected heterozygosity was 0.071-0.092 (1.3 times differences, being the highest

Table 1. Geographical coordinates and geographical distance $(\mathrm{km})$ among populations of I. parviflora

\begin{tabular}{|c|c|c|c|c|c|}
\hline Population & $\begin{array}{c}\text { Altitude, } \\
\text { m }\end{array}$ & Švenčionys & Ratnyčia & Žagarė & Karklè \\
\hline $\begin{array}{c}\text { Švenčionys, } \\
\text { N } 56^{\circ} 21^{\prime}-\mathrm{E} 23^{\circ} 15^{\prime}\end{array}$ & 40 & - & - & - & - \\
\hline $\begin{array}{c}\text { Ratnyčia } \\
\text { N } 55^{\circ} 49^{\prime}-\mathrm{E} 21^{\circ} 04^{\prime} \\
\end{array}$ & 30 & 187.3 & - & - & - \\
\hline $\begin{array}{c}\text { Žagarè } \\
\mathrm{N} 55^{\circ} 03^{\prime}-\mathrm{E} 26^{\circ} 14^{\prime}\end{array}$ & 170 & 225.8 & 267.7 & - & - \\
\hline $\begin{array}{c}\text { Karklè } \\
\text { N } 54^{\circ} 00^{\prime}-\mathrm{E} 24^{\circ} 01^{\prime}\end{array}$ & 60 & 330.4 & 277.2 & 149.2 & - \\
\hline
\end{tabular}


Ta ble 2. I. parviflora polymorphic DNA generated by ten RAPD primers (total number of bands - 188)

\begin{tabular}{|c|c|c|c|c|c|c|c|}
\hline \multirow[b]{2}{*}{ RAPD primer } & \multirow[b]{2}{*}{ Sequence $5^{\prime} \rightarrow 3^{\prime}$} & \multirow[b]{2}{*}{$\begin{array}{l}\text { Annealing } \\
\mathrm{T}\left({ }^{\circ} \mathrm{C}\right)\end{array}$} & \multirow{2}{*}{$\begin{array}{l}\text { Length of } \\
\text { DNA bands, bp }\end{array}$} & \multicolumn{3}{|c|}{ Number of bands } & \multirow{2}{*}{$\begin{array}{c}\text { Percentage of } \\
\text { polymorphic } \\
\text { bands }\end{array}$} \\
\hline & & & & $\begin{array}{l}\text { RAPD } \\
\text { primer }\end{array}$ & monomorphic & polymorphic & \\
\hline 222 & AAG CCT CCC C & 34 & $210-2500$ & 22 & 1 & 21 & 95.45 \\
\hline 250 & CGA CAG TCC C & 34 & $250-2500$ & 21 & 2 & 19 & 90.48 \\
\hline 269 & CCA GTT CGC C & 34 & $250-1200$ & 20 & 0 & 20 & 100.00 \\
\hline 340 & GAG AGG CAC C & 34 & $290-1800$ & 20 & 2 & 18 & 90.00 \\
\hline 474 & AGG CGG GAA C & 34 & $300-1700$ & 19 & 2 & 17 & 89.47 \\
\hline 516 & AGC GCC GAC G & 36 & $220-1100$ & 18 & 0 & 18 & 100.00 \\
\hline OPA-20 & GTT GCG ATC C & 32 & $450-2900$ & 18 & 0 & 18 & 100.00 \\
\hline OPB-7 & GGT GAC GCA G & 34 & $300-2000$ & 14 & 1 & 13 & 92.86 \\
\hline OPD-20 & ACC CGG TCA C & 34 & $280-2200$ & 20 & 0 & 20 & 100.00 \\
\hline OPQ-11 & TCT CCG CAA C & 34 & $300-2800$ & 16 & 0 & 16 & 100.00 \\
\hline $\begin{array}{l}\text { All primers } \\
\text { (total) }\end{array}$ & & $32-36$ & $210-2900$ & 188 & & & \\
\hline
\end{tabular}

Table 3. I. parviflora polymorphic DNA generated by separate RAPD primers (total number of the bands - 188)

\begin{tabular}{|c|c|c|c|c|c|c|c|c|c|c|}
\hline \multirow{2}{*}{ Population } & \multicolumn{10}{|c|}{ RAPD primers } \\
\hline & 222 & 250 & 269 & 340 & 474 & 516 & OPA-20 & OPB-7 & OPD-20 & OPQ-11 \\
\hline & \multicolumn{10}{|c|}{ Number of polymorphic bands } \\
\hline Švenčionys & 3 & 4 & 5 & 2 & 12 & 0 & 7 & 10 & 1 & 0 \\
\hline Ratnyčia & 2 & 8 & 8 & 0 & 11 & 0 & 6 & 3 & 1 & 2 \\
\hline Karklè & 2 & 6 & 8 & 0 & 9 & 0 & 8 & 2 & 1 & 4 \\
\hline \multirow[t]{2}{*}{ Žagarè } & 2 & 8 & 6 & 4 & 7 & 0 & 11 & 10 & 2 & 0 \\
\hline & \multicolumn{10}{|c|}{ Percentage of polymorphic bands } \\
\hline Švenčionys & 13.6 & 19.1 & 25.0 & 10.0 & 63.2 & 0 & 38.9 & 71.4 & 5.0 & 0 \\
\hline Ratnyčia & 9.1 & 38.1 & 40.0 & 0 & 57.9 & 0 & 33.3 & 21.4 & 5.0 & 12.5 \\
\hline Karklè & 9.1 & 28.6 & 40.0 & 0 & 47.4 & 0 & 44.4 & 14.3 & 5 & 25 \\
\hline Žagarè & 9.1 & 38.1 & 30.0 & 20.0 & 36.8 & 0 & 61.1 & 71.4 & 10.0 & 0 \\
\hline
\end{tabular}

for Žagarè population and the lowest for Ratnyčia population) it might be caused by differences in the size of population - Žagare population was scattered and big, while Ratnyčia population - the smallest in size and very compact. For each population the percentage of polymorphic bands with all primers was 21-27 (the lowest for Karkle and the highest for Žagare population) and the number of polymorphic band ranged in the interval 40-50. Molecular variance among populations was much higher $(82 \%)$ than within populations (18\%; Fig. 2).

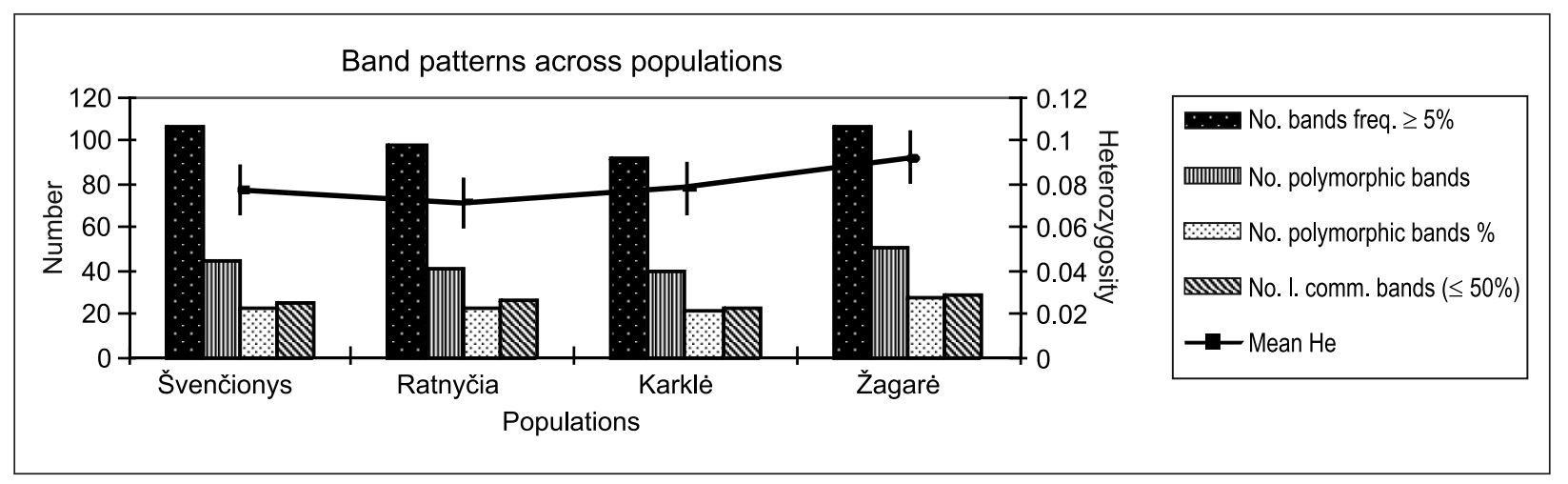

Fig. 1. Total DNA band patterns for geographically contrasting 4 populations of $I$. parviflora growing in Lithuania (No. bands freq. - number of different bands with a frequency $\geq 5 \%$. No. polymorphic bands - number of polymorphic bands in all primers. No. polymorphic bands $\%$ - number percentage polymorphic bands in all primers. No. I. comm. bands - number of locally common bands found in $\leq 50 \%$ populations. He - expected heterozygosity) 


\section{Percentages of Molecular Variance}

Within Pops

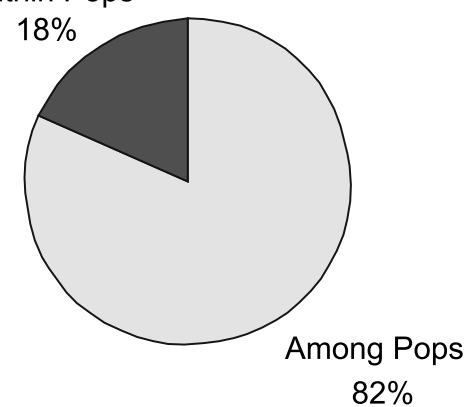

Fig. 2. Results with 10 primers of molecular variance of four I. parviflora populations in Lithuania
Relationships between populations according to the bands generated by different RAPD primers gave two types of dendrograms (Fig. 3). One type was an asymmetric tree with one branch - one of populations was very distinct from the other branch with three populations. The tree of other type consisted of two more or less equal branches with 2 populations in each. It was true for 250, OPD-20 and $\mathrm{OPQ}-11$ primers. In two equal branch trees always the same pairs of populations separated: east-south and north-west population. In case of asymmetric tree the most distinct population depended on the primer: for 222 and OPD-20 primers the most different population was from the southern part of Lithuania (Ratnyčia), for primers 340 and OPB-7 the most distinct population was from the west (Karkle)), for 269 and 516 primers the east part

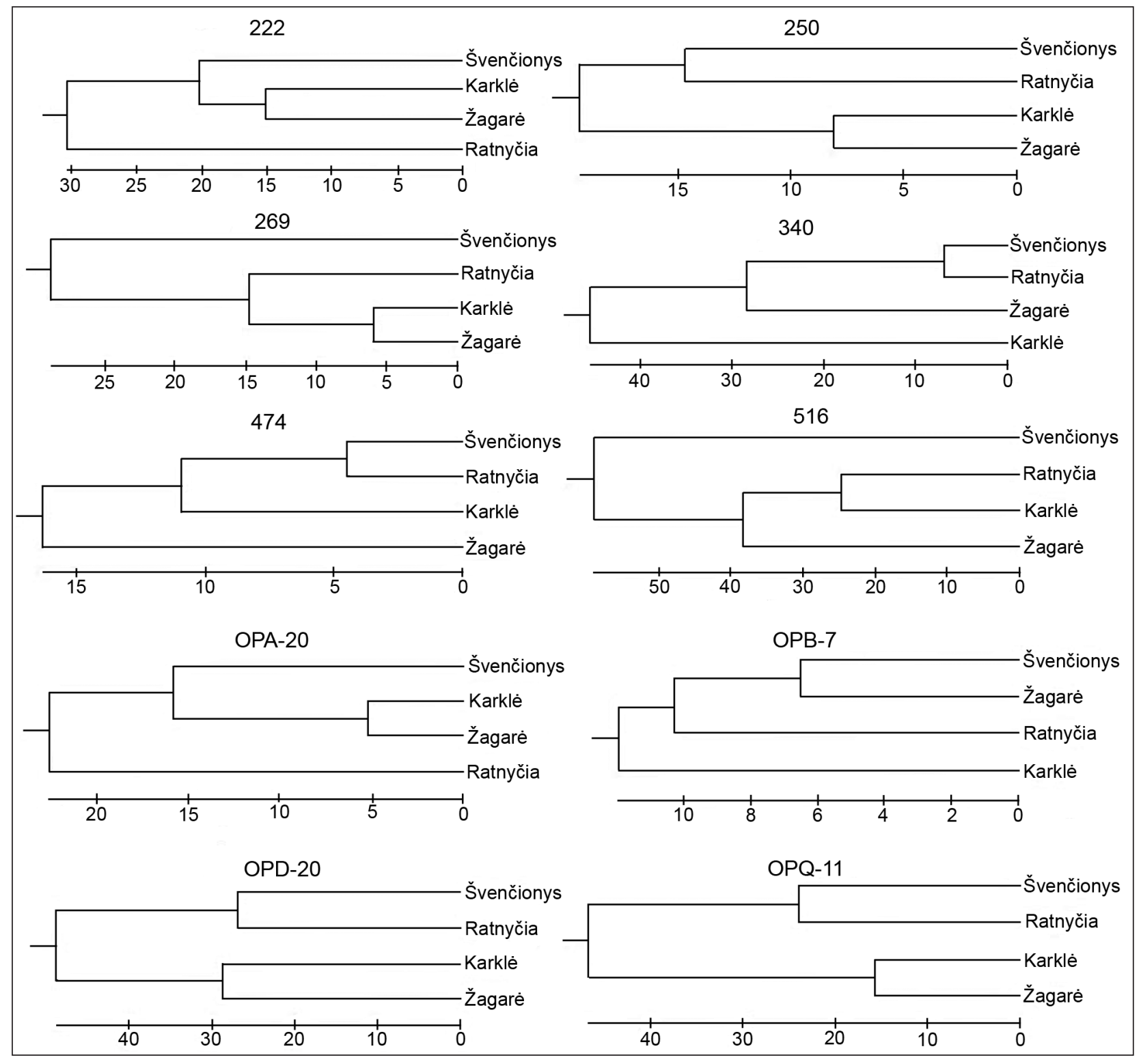

Fig. 3. Genetic relationships among 4 populations of $I$. parviflora based on ten separate RAPD primers using the UPGMA algorithm and the genetic distance (GD according to Nei and Li [13]) 
population (Švenčionys) was distinguished from the others and for one primer (474) the north population (Žagarè) was most distinct. It shows that different DNA RAPD primers might be useful markers specifying populations. The classifications obtained by 250 , OPD-20 and OPQ- 11 primers reflected relationships between individuals of 4 populations according to all examined primers using Nei and Li [13] genetic distance matrix (bootstrap values obtained after 1000 iterations) and UPGMA method (Fig. 4). Each of 80 examined individuals revealed different RAPD phenotype (i. e. 80 RAPD phenotypes). Principal coordinate analyses confirmed UPGMA data (Fig. 5) and reflected genetic distances among populations very well: ŠvenčionysŽagarė 0.583, Švenčionys-Karklè 0.572, Ratnyčia-Žagarė 0.560, Ratnyčia-Karklè 0.444, Švenčionys-Ratnyčia 0.443 . The shortest genetic distance Karklè-Žagarè 0.349 corresponded to the shortest geographical distance $(149 \mathrm{~km})$.

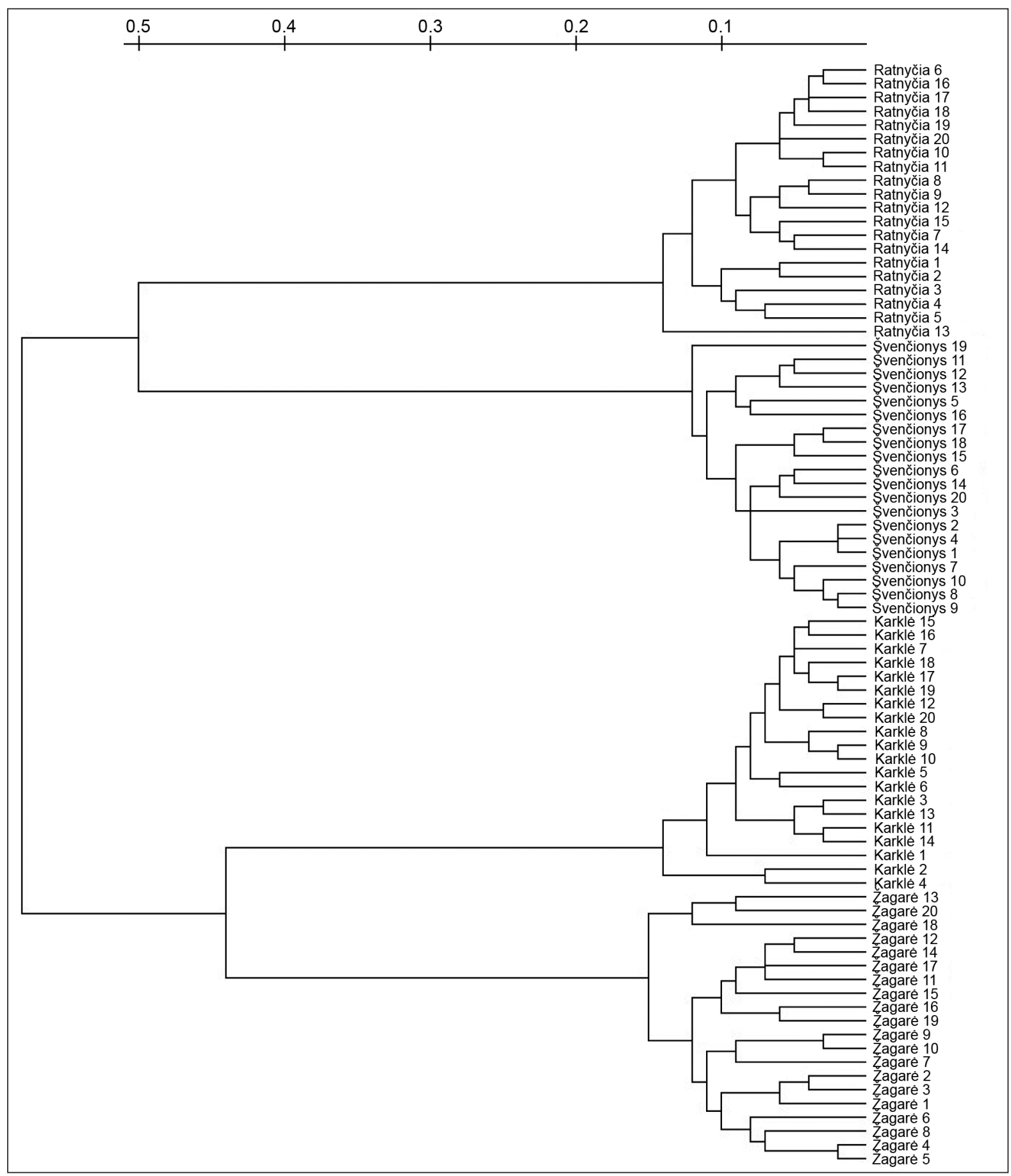

Fig. 4. Genetic relationships among 4 populations of $I$. parviflora based on ten RAPD primers using the UPGMA algorithm and the genetic distance (GD according to Nei and Li [13]) 


\section{Principal Coordinates}

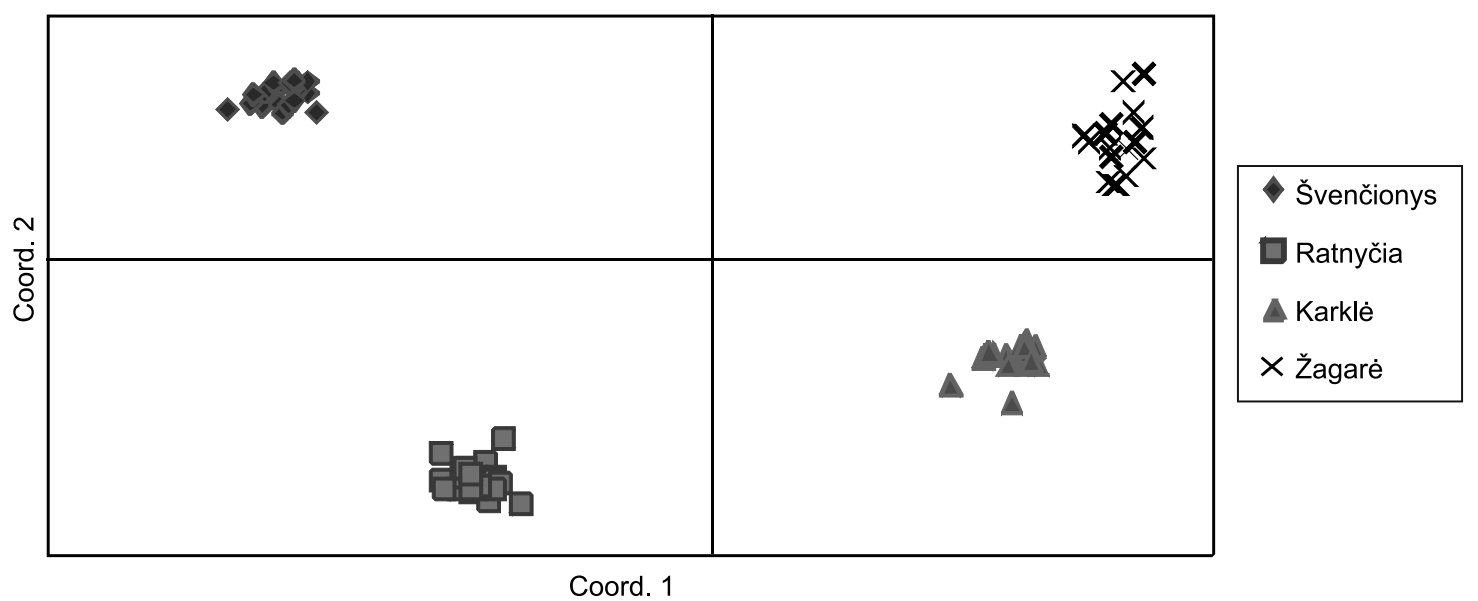

Fig. 5. Principal coordinate analyses of genetic distance of four I. parviflora populations from Švenčionys, Ratnyčia, Karklè, Žagarė with 10 RAPD primers

\section{CONCLUSIONS}

The obtained data show that distribution of invasive species might bring changes in genetic diversity. Selected RAPD primers generated from 14 to 22 bands each, most of the bands (13-20 bands in primer) were polymorphic, and percentage of polymorphic bands was $89-100$, respectively, merely a few bands in some primers (1-2 bands in primer) were monomorphic. For each population the percentage of polymorphic bands with all primers was 21-27 (the lowest for Karklè and the highest for Žagare population). UPGMA dendrograms (both for populations and for individuals) revealed genetic differentiation among populations. In two equal branch trees always the same pairs of populations separated: east-south and northwest population. In case of an asymmetric tree, the most distinct population depended on the primer: for 222 and OPD-20 primers the most different population was from the southern population (Ratnyčia). The shortest genetic distance Karklè-Žagare corresponded to the shortest geographical distance $(149 \mathrm{~km})$. Principal coordinate analyses of RAPD data confirmed UPGMA dendrogram results. Based on different RAPD primers, principal component analyses provided the best information about geographical location of populations.

\section{ACKNOWLEDGEMENTS}

The work was sponsored by Council of Science of Lithuania, Grant LEK-04/2010.

Received 13 October 2011 Accepted 31 October 2011

\section{References}

1. McKinney ML, Lockwood JL. Biotic homogenisation: a few winners replacing many losers in the next mass extinction. Tree 1999; 14: 450-3.

2. Dortmontt EE, Lowe AJ, Prentis PJ. Is rapid adaptive evolution important in successful invasions? In: Fifty years of Invasion Ecology: The legacy of Charles Elton, 1st ed. Richardson DM (ed.), Oxford: Blackwell Publishing LTd, 2011; 175-93.

3. Hegi G. Illustrierte Flora von Mittel-Europa, Muenchen 1906; 1: 319.

4. Natkevicaite-Ivanauskienè M. Adventive flora of Lithuanian Soviet Republic. Proceedings of Institute of Biology 1951; 1: 77-124 (in Lithuanian).

5. Chittka L, Schürkens S. Successful invasion of floral market. Nature 2001; 411: 653.

6. Pyšek P, Prach K. Invasion dynamics of Impatiens glandulifera - a century of spreading reconstructed. Biol Conserv 1995; 74: 41-8.

7. Kuusk V, Tabaka L, Jankeviciene R. Flora of the Baltic Countries. Compendium of Vascular Plants, Eesti Loodusfoto AS Tartu 1996; 2: 177.

8. Chmura D, Sierka E. Relation between invasive plant and species richness of forest floor vegetation: a study of Impatiens parviflora DC. Polish J Ecol 2006; 54(3): 417-28.

9. Chmura D, Sierka E. The invasibility of decidous forest communities after disturbance: A case study of Carex brizoides and Impatiens parviflora invasion. Forest Ecol Manag 2007; 242: 487-95.

10. Priede A. Distribution of some invasive alien plant species in riparian habitats in Latvia. Botanica Lithuanica 2008; 14(3): 137-50. 
11. Gudzinskas Z, Sinkeviciene Z. Distribution, biology and naturalization of Impatiens glandulifera Royle (Balsaminaceae) in Lithuania. Botanica Lithuanica 1995; 1: 21-3.

12. Paulauskas A, Jodinskienè M, Radzijevskaja J, Kupcinskiene E, Lygis D, Ozeraitiene D, Skuodiene R. Modelling of minimal distances from GM oilseed rape in Lithuania. GMOs in Integrated Plant Production. IOBC/wprs Bulletin 2010; 52: 75-84.

13. Nei M, Li WH. Mathematical model for studying genetic variation in terms of restriction endonucleases. Proc Nat Acad Scien USA 1979; 76(10): 5269-73.

14. Peakall R, Smouse P. GenAlEx v. 6: genetic analysis in Excel. Population genetic software for teaching and research. Mol Ecol Notes 2006; 6: 288-95.
Rasa Janulionienė, Judita Žukauskienė, Milda Jodinskienė,

Daiva Ambrasienè, Algimantas Paulauskas,

Eugenija Kupčinskienė

\section{GEOGRAFIŠKAI LABIAUSIAI NUTOLUSIŲ IMPATIENS PARVIFLORA POPULIACIJŲ LIETUVOJE APPD PRADMENU PARINKIMAS}

\section{Santrauka}

Nedaug tyrimų atlikta aiškinantis invazinių augalų rūšių plitimo būdus Baltijos šalyse. Manoma, kad smulkiažiedè sprigè (Impatiens parviflora DC.) pirmą kartą buvo pastebėta Vilniaus priemiesčiuose 1934 m. ir kad ji paplito iš VU Botanikos sodo. Šiuo metu smulkiažiedè sprigè išplitusi žmogaus dažnai lankomose, gyvenamose vietose - miestuose, pakelèse ar kaimo sodybose. Perteklinio drègnio miškai taip pat yra dažnos smulkiažiedès sprigès augavietės. Mūsų tyrimo tikslas - palyginti prie Lietuvos vakarinès, pietinès, šiaurinès ir rytinès sienų (Karklè, Ratnyčia, Žagarès, Švenčionių) augančios smulkiažiedès sprigès populiacijų genetinę ịvairovę su geografine padètimi. I. parviflora populiacijų genetinès ịvairovès vertinimui buvo pasirinktas atsitiktinai pagausintos polimorfinès DNR (APPD) metodas. Iš tirtų trisdešimt APPD pradmenų daugiausiai DNR atkarpų pagamino 222, 250, 269, 340, 474, 516, OPA-20, OPB-7, OPD-20, OPQ-11 pradmenys. Atrinkta ir ištirta dvidešimt individų populiacijoje. Keturiose I. parviflora populiacijose su dešimčia pradmenų susidarè 21-27\% polimorfinių fragmentų, o jų skaičius siekè nuo 40 iki 50. Tarppopuliacinè genetinè ịvairovè buvo daug didesnè (82\%) nei populiacijos viduje. Genetinis atstumas tarp populiacijų svyravo nuo 0,349 iki 0,583 . Geografiškai skirtingų vietų populiacijų tarpusavio skirtumai atsispindejo pagal APPD metodą susiformavusiose UPGMA dendrogramose, taip pat analizuojant principines koordinates. Gauti duomenys rodo, kad plintant svetimžemèms, invazinèms rūšims galimi genetinès ịvairovès pokyčiai.

Raktažodžiai: smulkiažiedè sprigè, balzaminių šeima, polimorfizmas, invazija, svetimžemès rūšys 